\title{
Cupric Sulfate Intoxication with Rhabdomyolysis, Treated with Chelating Agents and Blood Purification
}

\author{
Taichi Takeda, Tetsuo Yukioka and Syuji Shimazaki
}

\begin{abstract}
We report a case of cupric sulfate intoxication complicated by hemolytic anemia, hepato-renal damage and acute rhabdomyolysis. The patient was successfully treated with dimercaprol, penicillamine, direct hemoperfusion and hemodiafiltration. We discuss the pathophysiology of cupric intoxication, and propose a treatment combined with chelating agents and blood purification.

(Internal Medicine 39: 253-255, 2000)
\end{abstract}

Key words: copper intoxication, direct hemoperfusion, hemodiafiltration

\section{Introduction}

Cupric sulfate is commercially available and found in products of fungicides for tropical fish in Japan. However, the pathophysiology of acute copper intoxication is not well understood and its management has not been established. We describe a case of cupric sulfate intoxication with acute rhabdomyolysis treated successfully with dimercaprol, penicillamine, hemoperfusion and hemodiafiltration.

\section{Case Report}

A healthy 18-year-old man without a significant past medical history was brought to the hospital one hour after drinking a solution as a suicidal attempt containing approximately $8 \mathrm{~g}$ of cupric sulfate, which he had been using for chemistry experiments. He was lethargic and vomiting spontaneously. Blue staining of the oral mucosa and vomitus on his clothes were noticed. The temperature was $36.2^{\circ} \mathrm{C}$, the pulse rate was 92 , the respirations were 30 , and the blood pressure was $160 / 64$ $\mathrm{mmHg}$. No neurological focal sign was present on examinations. The laboratory data revealed hemoconcentration with $18.7 \mathrm{~g} / \mathrm{dl}$ of hemoglobin and 55\% of hematocrit. Although indirect bilirubin was $1.4 \mathrm{mg} / \mathrm{dl}$, other renal and liver function tests remained in the normal limit as shown in Table 1. Radiographs of the chest and abdomen were unremarkable. The patient was intubated, and gastric lavage was performed to remove the ingested blue solution. He was put on dimercaprol $1,800 \mathrm{mg} /$ day and penicillamine $900 \mathrm{mg} /$ day.

The next day, the urine color was noted to be a brown-red color. Urinalysis revealed hemoglobin, myoglobin $(1,015 \mu \mathrm{g} /$ day) and granular casts. Serum creatine phosphokinase (CPK) level was elevated to $519 \mathrm{IU} / \mathrm{l}$ (Fig. 1) and serum myoglobin level was over $300 \mathrm{ng} / \mathrm{ml}$. Hemolysis and rhabdomyolysis were diagnosed, and acute tubular necrosis was suspected. In order to prevent the worsening of the acute renal failure, hydration was continued to maintain urine output (Fig. 2). Haptoglobin was administered for hemolysis. In addition, a double lumen catheter was placed in the right femoral vein for access for blood purification. Four sessions of direct hemoperfusion (DHP) for 4 hours using activated charcoal (Hemokalum ${ }^{\circledR}$, Terumo, Tokyo) and 5 sessions of hemodiafiltration (HDF) for 4 hours without volume depletion using a polysulfone hollow fiber dialyzer with a membrane area of $1.25 \mathrm{~m}^{2}$ (Fresenius Dialyzer PS-1.3UW ${ }^{\circledR}$, Kawasumi Laboratories, Inc., Tokyo) were performed in 6 days to remove copper, hemoglobin, myoglobin and other debris from injured tissue. Nafamostat mesilate, a protease inhibitor, was applied as an anticoagulant at a dose of $0.2 \mathrm{mg} / \mathrm{kg} /$ hour during the blood purification.

CPK became elevated to $3,804 \mathrm{IU} / \mathrm{l}$ on the 6 th day, and declined thereafter (Fig. 1). Serum urea nitrogen (UN), serum creatinine (CRE), creatinine clearance (Ccr) and excreted fraction of filtered sodium (FENa) was retained within the normal range during the treatment period. Urine color became clear yellow on the 8th hospital day. On the 10th day, the blood hemoglobin $(\mathrm{Hb})$ level decreased to $7.2 \mathrm{~g} / \mathrm{dl}$ and hematocrit $(\mathrm{Ht})$ went down to $22.0 \%$ due to hemolysis, and thrombocytosis and hyperbilirubinemia followed afterward. Aspartate aminotransferase (AST) peaked at $119 \mathrm{IU} / \mathrm{l}$ on the 6th day and alanine aminotransferase (ALT) increased to $124 \mathrm{IU} / l$ on the 18th day, and both liver function parameters subsided afterward.

Serum copper $(\mathrm{Cu})$ concentration was $142 \mu \mathrm{g} / \mathrm{dl}$ (normal limit 78-131) on admission, and the urine copper excretion

From the Department of Traumatology and Critical Care Medicine, Kyorin University School of Medicine, Tokyo

Received for publication November 19, 1998; Accepted for publication September 21, 1999

Reprint requests should be addressed to Dr. Taichi Takeda, the Department of Traumatology and Critical Care Medicine, Kyorin University School of Medicine, Shinkawa 6-20-2, Mitaka, Tokyo 181-8611 
Table 1. The Laboratory Findings on Admission

\begin{tabular}{lr}
\hline Hematologic laboratory values: & \\
Hemoglobin & $18.7 \mathrm{~g} / \mathrm{dl}$ \\
Hematocrit & $55.0 \%$ \\
White cell count & $10.4 \times 10^{3} / \mu \mathrm{l}$ \\
Platelet count & $23.1 \times 10^{4} / \mu \mathrm{l}$ \\
Prothrombin time & $100 \%$ \\
Activated partial thromboplastin time & $32.3 \mathrm{~second}$ \\
& \\
Blood chemical findings: & \\
Sodium & $141 \mathrm{mmol} / l$ \\
Potassium & $3.1 \mathrm{mmol} / l$ \\
Chloride & $100 \mathrm{mmol} / l$ \\
Calcium & $10 \mathrm{mg} / \mathrm{dl}$ \\
Urea nitrogen & $9.5 \mathrm{mg} / \mathrm{dl}$ \\
Creatinine & $0.7 \mathrm{mg} / \mathrm{dl}$ \\
Total protein & $8.9 \mathrm{~g} / \mathrm{dl}$ \\
Albumin & $5.9 \mathrm{~g} / \mathrm{dl}$ \\
Total bilirubin & $1.4 \mathrm{mg} / \mathrm{dl}$ \\
Direct bilirubin & $0.3 \mathrm{mg} / \mathrm{dl}$ \\
Indirect bilirubin & $1.1 \mathrm{mg} / \mathrm{dl}$ \\
Alkaline phosphatase & $175 \mathrm{IU} / l$ \\
Cholinesterase & $5,466 \mathrm{IU} / l$ \\
Aspartate aminotransferase & $29 \mathrm{IU} / l$ \\
Alanine aminotransferase & $16 \mathrm{IU} / l$ \\
Lactate dehydrogenase & $394 \mathrm{IU} / l$ \\
Creatine phosphokinase & $163 \mathrm{IU} / l$ \\
Amylase & $151 \mathrm{IU} / l$ \\
Glucose & $131 \mathrm{mg} / \mathrm{dl}$ \\
C-reactive protein & $0.0 \mathrm{mg} / \mathrm{dl}$ \\
Copper & $142 \mu \mathrm{g} / \mathrm{dl}$ \\
\hline & \\
& \\
&
\end{tabular}

was $3.95 \mathrm{mg} /$ day during the first day. Since most of the absorbed copper binds to serum and tissue proteins, estimation of copper contents in the patient was considered impractical (1). Excess copper is excreted gradually, and chelates were thought to accelerate excretion through urine and artificial blood purification. The patient was discharged on the 15th hospital day, and treatment with penicillamine was continued for 4 weeks until hemolytic anemia was resolved. No complication was noticed during the 8-weeks follow-up period.

\section{Discussion}

The lethal dose of cupric sulfate has been described to be as low as $1 \mathrm{~g} \mathrm{(2).} \mathrm{Ingested} \mathrm{copper} \mathrm{induces} \mathrm{mucous} \mathrm{irritation,} \mathrm{nau-}$ sea, vomiting and diarrhea. Ionized copper is rapidly absorbed from the stomach and intestine, and the serum copper level increases rapidly. The element is bound to albumin and ceruloplasmin, and is taken up by the liver, kidneys, lungs and red blood cells. Hemolytic anemia and renal tubular necrosis may follow 36-48 hours after exposure. The primary route of excretion is through bile and feces (3).

The toxicity of copper at a cellular level is probably related to the sulfhydryl groups. Copper inhibits the sulfhydryl moieties of glucose-6-phosphate dehydrogenase and glutathione,

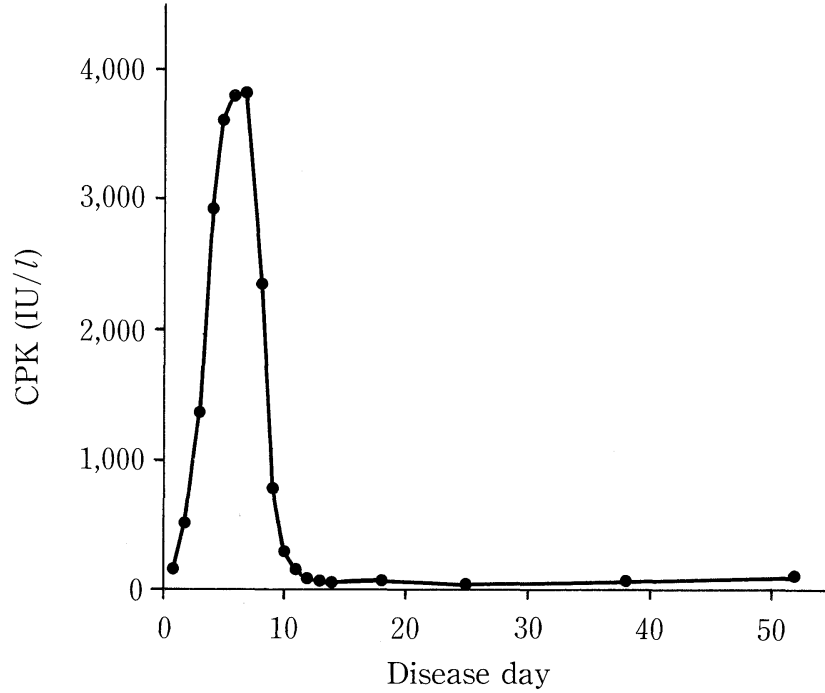

Figure 1. Serum creatine phosphokinase (CPK) level.

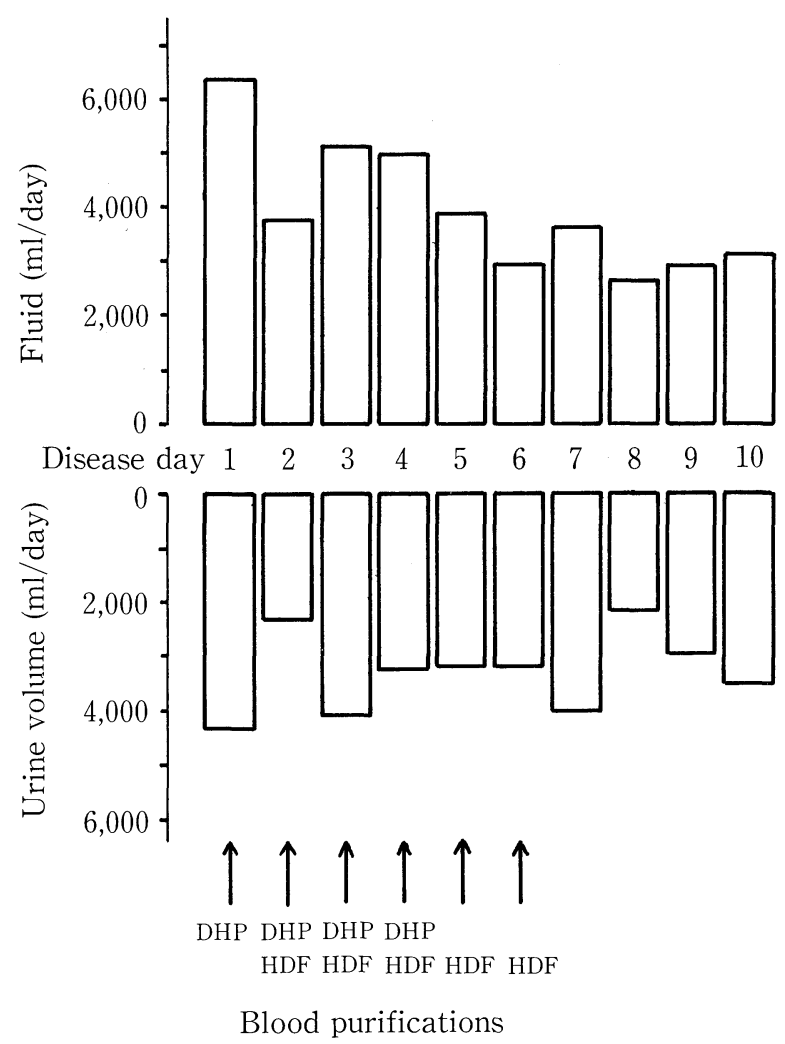

Figure 2. Hydration and urine output in the beginning of treatment. Direct hemoperfusion and hemodiafiltration without volume depletion were performed in 6 days. DHP: direct hemoperfusion, HDF: hemodiafiltration. 


\section{Cupric Sulfate Intoxication}

thereby reducing their free radical scavenging activities. Copper induces hemolysis through oxidation of hemoglobin sulfhydryl groups. Copper also inhibits $\mathrm{Na}+\mathrm{K}(+)$-ATPase and increases the permeability of cell membrane. Since copper is known to damage human skeletal muscle cells (4), copper intoxication could cause rhabdomyolysis. Although a case of copper-induced acute rhabdomyolysis in Wilson's disease was reported (5), rhabdomyolysis in acute copper intoxication has been rarely reported (3). This might be because myoglobinuria might be overlooked by the coexistence of hemoglobinuria secondary to hemolytic anemia.

The treatment for ingested copper overdosage includes dermal decontamination, cautious gastric lavage and supportive therapy (6). Dimercaprol, penicillamine and edetate calcium disodium might be considered for massive copper ingestion, and persistent symptomatology or persistently elevated serum copper concentrations. For serious poisoning, it is considered best to administer dimercaprol intramuscularly $4 \mathrm{mg} / \mathrm{kg} / \mathrm{dose}$ every 4 hours for 5-7 days. Penicillamine is usually administered orally in doses of 250-500 mg/dose every 8-12 hours. Edetate calcium disodium is also a drug of choice, but the agent has not been approved in Japan for copper intoxication and so was not used in this case. Dialysis or hemoperfusion has not been demonstrated to increase the elimination of copper, since copper binds to serum and tissue proteins. However, chelated copper would be removed from serum by diuresis and dialysis. Especially in this case direct hemoperfusion and hemodiafiltration were performed to eliminate chelated copper and nephrotoxic substances, and the patient was successfully treated without developing acute renal failure. Then necessity of plasma exchange has not been established.

In summary, we described a case of cupric sulfate intoxication with rhabdomyolysis, treated with a combination of chelating agents and blood purification.

Acknowledgements: This work was supported by the Department of Traumatology and Critical Care Medicine, Kyorin University School of Medicine. The authors thank Dr. Takeda (University of Tsukuba) for her professional assistance.

\section{References}

1) Manzler AD, Schreiner AW. Copper-induced acute hemolytic anemia. A new complication of hemodialysis. Ann Intern Med 73: 409-412, 1970.

2) Stein RS, Jenkins D, Korns ME. Death after use of cupric sulfate as emetic. JAMA 235: 801, 1976.

3) Jantsch W, Kulig K, Rumack BH. Massive copper sulfate ingestion resulting in hepatotoxicity. Clin Toxicol 22: 585-588, 1985.

4) Benders AA, Li J, Lock RA, Bindels RJ, Bonga SE, Veerkamp JH. Copper toxicity in cultured human skeletal muscle cells: the involvement of $\mathrm{Na}^{+} / \mathrm{K}^{+}$-ATPase and the $\mathrm{Na}^{+} / \mathrm{Ca}^{2+}$-exchanger. Pflugers Arch 428: 461-467, 1994.

5) Propst A, Propst T, Feichtinger H, Judmaier G, Willeit J, Vogel W. Copper-induced acute rhabdomyolysis in Wilson's disease. Gastroenterology 108: 885-887, 1995.

6) Leikin JB, Paloucek. Poisoning \& Toxicology Handbook. 2nd ed. 199697. Lexi-Comp Inc., Ohio, 1995: 896-898. 